\title{
Human Autoantibodies to Poly(Adenosine Diphosphate-Ribose) Polymerase
}

Hisashi Yamanaka, Erik H. Willis, Carol A. Penning, Carol L. Peebles, Eng M. Tan, and Dennis A. Carson

Department of Basic and Clinical Research, Research Institute of Scripps Clinic, La Jolla, California 92037

\begin{abstract}
The chromatin-bound enzyme poly(ADP-ribose) polymerase (ADPRP) is strongly stimulated by DNA with single- or double- stranded breaks, and transfers the ADP-ribose moiety of NAD to nuclear proteins. The activation of ADPRP is important for DNA repair and replication, and also has been postulated to play a role in the pathogenesis of lymphocyte dysfunction associated with chronic inflammatory diseases, and inborn errors of nucleoside metabolism. We have detected high titers of IgG autoantibodies to the ADPRP protein in six patients with rheumatic complaints. No other autoantibodies were detected in any of the six sera. The specificity of the anti-enzyme antibodies was established by (a) immunoprecipitation of ADPRP activity, (b) immunoprecipitation and immunoblotting of both the native 116-kD enzyme and its proteolytic digestion products. ADPRP was purified from human thymus and calf thymus. The autoantibodies reacted equivalently with both enzymes. The anti-ADPRP antibodies had a distinctive immunofluorescent pattern with HEp-2 cells, reacting intensely with nucleoli and metaphase chromosomes, and diffusely with the nucleus. Autoantibodies to ADPRP have not been described previously. The presence of a specific immune response against an enzyme that has been associated with various immunodeficiency syndromes raises intriguing possibilities concerning the relationship between DNA damage, immunodeficiency, and autoimmunity.
\end{abstract}

\section{Introduction}

The nuclear enzyme poly(ADP-ribose) polymerase (ADPRP) ${ }^{1}$ requires double-stranded DNA for catalytic activity and is stimulated strongly by DNA containing single- or double-

Portions of this work were presented in abstract form in November, 1986, at the Western Regional Meeting of the American Rheumatism Association, in Vancouver, British Columbia, Canada.

This is Publication No. 4689BCR from the Research Institute of Scripps Clinic.

Address reprint requests to Dr. Carson, Research Institute of Scripps Clinic, 10666 North Torrey Pines Road, La Jolla, CA 92037.

Received for publication 27 February 1987 and in revised form 18 May 1987.

1. Abbreviation used in this paper: ADPRP, poly(ADP-ribose) polymerase.

J. Clin. Invest.

(c) The American Society for Clinical Investigation, Inc.

0021-9738/87/09/0900/05 \$2.00

Volume 80, September 1987, 900-904 stranded breaks (1). Using NAD as a substrate, the enzyme adds elongated and branched poly(ADP-ribose) chains to chromatin-bound proteins $(2,3)$, including the ADPRP enzyme itself (4). Poly(ADP-ribosyl)ation modulates the interaction between DNA and nuclear proteins (5). The synthesis of poly(ADP-ribose) is thought to play a positive role in the DNA excision-repair process $(6,7)$, especially at the DNA ligation step (8). However, the excessive activation of ADPRP can also impair cell function and survival by depleting NAD pools $(9$, 10) and by inactivating nuclear enzymes (11).

ADPRP is found mainly in complex multicellular organisms (12). A major function of the enzyme may be to inactivate and eliminate somatic cells with damaged DNA $(7,13)$. Recently, the unrestrained formation of poly(ADP-ribose) in lymphocytes has been postulated to be a possible cause of immune dysfunction in patients with inborn errors of adenine nucleoside metabolism, and in chronic inflammatory diseases (14).

DNA-binding proteins are established targets of autoimmunity in patients with systemic autoimmune diseases (15, 16). Considering the possible role of ADPRP in the pathogenesis of immunodeficiency, and the ability of the enzyme to undergo DNA-dependent automodification (4), it was conceivable that ADPRP could represent a potential autoantigen. For these reasons, we systematically searched for autoantibodies to ADPRP in human sera. Here we report our initial findings concerning the presence of high titer, monospecific autoantibodies to ADPRP in a group of patients with rheumatic disorders.

\section{Methods}

Materials. All patient sera came from the antinuclear antibody-positive serum bank at the Autoimmune Disease Center of Research Institute of Scripps Clinic. Sera from normal blood donors with antinuclear antibodies were kindly provided by Dr. Marvin Fritzler (University of Calgary, Calgary, Alberta, Canada). Unless otherwise stated, all chemicals were purchased from Sigma Chemical Co. (St. Louis, MO).

Immunoprecipitation of poly(ADP-ribosyl)ated cellular protein. Nuclear proteins of the human $\mathrm{T}$ lymphoblastoid cell line CCRF-CEM were poly(ADP-ribosyl)ated with $\left[{ }^{32} \mathrm{P}\right] \mathrm{NAD}(16.3 \mathrm{Ci} / \mathrm{mmol} \mathrm{sp}$ act, New England Nuclear, Boston, MA) according to the method of Berger et al. $(6,17)$. Then, cells were lysed in NET-2 buffer $(50 \mathrm{mM}$ Tris- $\mathrm{HCl}$, pH 7.4, $150 \mathrm{mM} \mathrm{NaCl}, 0.5 \%$ Nonidet P-40, $0.5 \%$ sodium deoxycholate, $0.1 \%$ sodium dodecyl sulfate (SDS), $5 \mathrm{mM}$ EDTA, and $0.5 \mathrm{mM}$ phenylmethyl-sulfonyl fluoride [PMSF]). Solubilized proteins were reacted for $2 \mathrm{~h}$ at $4^{\circ} \mathrm{C}$ with human serum IgG that had been immobilized previously onto protein A-Sepharose CL-4B beads (Pharmacia Fine Chemicals, Piscataway, NJ) (18). After centrifugaiton $(10,000 \mathrm{~g}$ for $2 \mathrm{~min}$ at $4^{\circ} \mathrm{C}$ ) and washing of the beads with NET-2 buffer, antibody-bound protein was solubilized in Laemmli's sample buffer (19) and boiled for $2 \mathrm{~min}$. Immunoprecipitated proteins were fractionated 


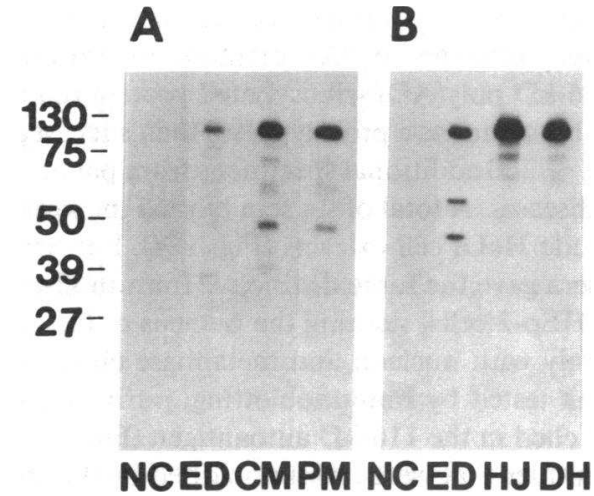

Figure 1. Immunoblotting of autoantibodies to ADPRP. $(A)$ Crude HeLa cell extract and $(B)$ purified nucleoli from transformed human amnion cells were fractionated on a $17.5 \%$ polyacrylamide gel containing $0.1 \%$ SDS, transferred onto nitrocellulose paper, and immunoblotted with 1:100 diluted sera of a normal control (NC) and patients (E.D., C.M., P.M., H.J., or D.H.). Bound antibody was detected with ${ }^{125}$ I-protein A. Molecular weight markers are shown on the left margin as kilodaltons.

on a $12.5 \%$ polyacrylamide gel containing $0.1 \%$ SDS, and autoradiographed.

Immunoblotting of HeLa cell extract and purified nucleoli. Con- fluent monolayers of HeLa cells were lysed in ice-cold buffer A (10 $\mathrm{mM}$ Tris-HCl, pH 7.4, $150 \mathrm{mM} \mathrm{NaCl}, 10 \mathrm{mM} \mathrm{MgCl}_{2}$, and $0.5 \%$ Nonidet $\mathrm{P}-40$ supplemented with $23 \mathrm{U} / \mathrm{ml}$ kallikrein inhibitor). After centrifugation, the supernatant was fractionated on a $17.5 \%$ polyacrylamide gel containing $0.1 \%$ SDS, and transferred onto nitrocellulose paper. A purified nucleoli fraction was obtained from the nuclear pellet of transformed human amnion cells (20) according to the method of Rothblum et al. (21). The crude HeLa cell extract and the purified nucleoli were immunoblotted with 1:100 diluted sera, and bound antibody was detected using ${ }^{125} \mathrm{I}$-protein A (New England Nuclear).

Immunofluorescent detection of autoantibodies to ADPRP. Acetone-fixed HEp-2 cells (Bion Enterprises, Ltd., Park Ridge, IL) were reacted with either a serum containing antibodies to ADPRP or affinity purified anti-ADPRP IgG, and followed by fluorescein-conjugated goat anti-human IgG (Tago, Burlingame, CA). Then the cells were examined under a Leitz fluorescent microscope.

Purification and analysis of ADPRP. ADPRP was purified from calf thymus ( $150 \mathrm{~g}$, Pel-Freeze Biologicals, Rogers, AK) and human thymus (obtained at cardiac surgery) according to the method of Carter et al. (22) through the hydroxyapatite column step.

1- $\mu \mathrm{g}$ aliquots of the purified calf thymus or human thymus ADPRP were treated for $2 \mathrm{~h}$ at $4^{\circ} \mathrm{C}$ with serial dilutions of antibody-coated Sepharose beads, exactly as described above. After centrifugation, the ADPRP enzyme activities in the antibody-treated supernatants were determined radiochemically (22).

To map the autoantigenic epitopes on ADPRP, $15 \mu \mathrm{g}$ of the purified calf enzyme was auto-poly(ADP-ribosyl)ated with $0.65 \mu \mathrm{M}$ $\left[{ }^{32} \mathrm{P}\right] N A D$ in the presence of $100 \mu \mathrm{g} / \mathrm{ml}$ calf thymus DNA, as described
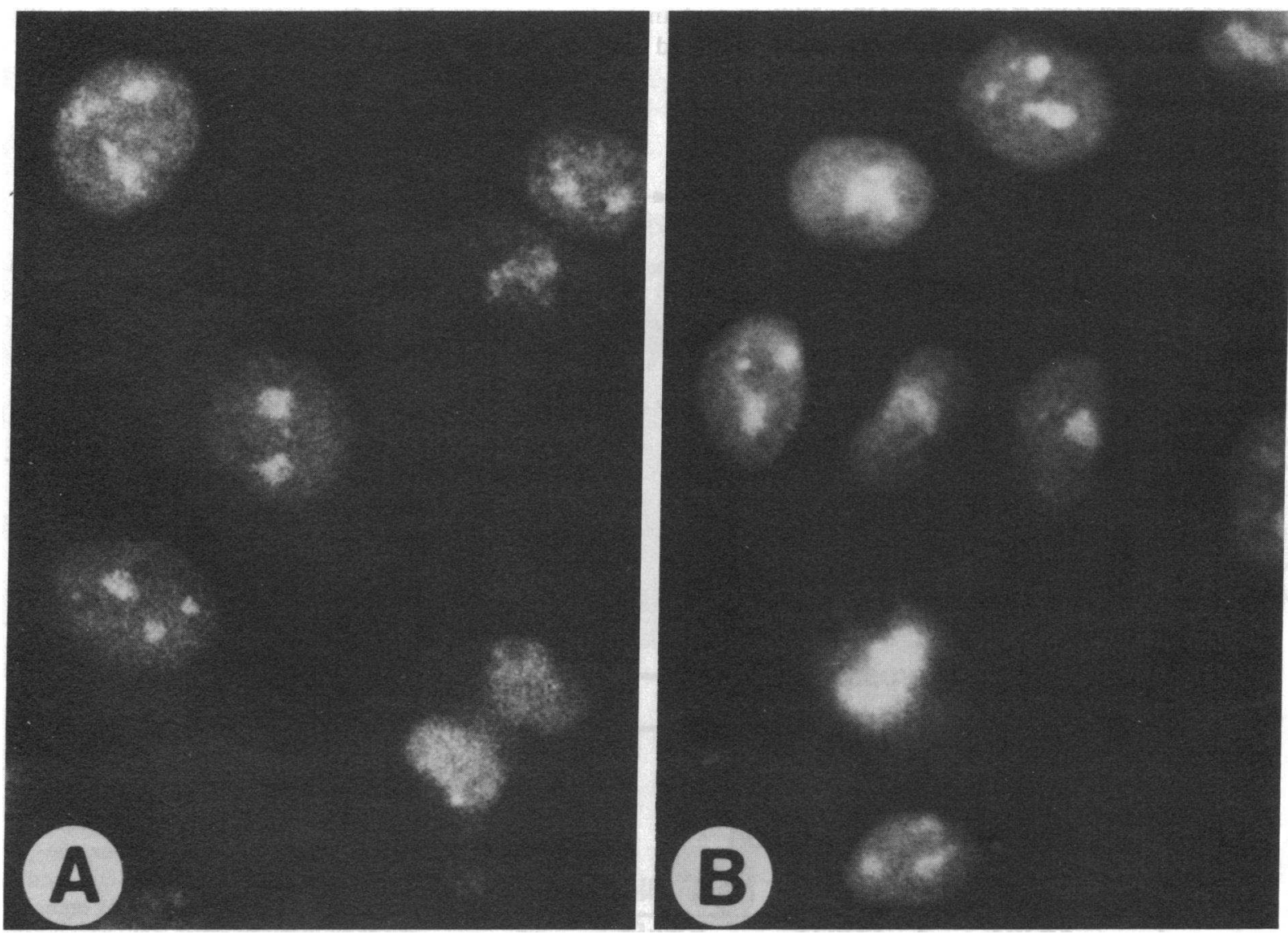

Figure 2. Immunofluorescent detection of autoantibodies to ADPRP. Acetone-fixed HEp-2 cells were examined by indirect immunofluorescent method using $(A)$ a serum containing antibodies to ADPRP or $(B)$ affinity purified anti-ADPRP IgG, as the first antibody, and fluorescein-conjugated goat anti-human IgG as the second antibody. The diffuse nuclear staining with nucleolar accentuation is apparent. 


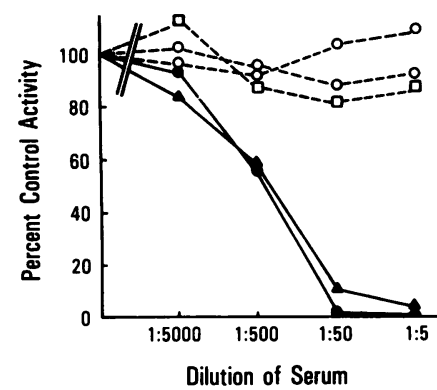

ties in the antibody-treated supernatants were determ pressed as percentages of the antibody-free control $(75.0 \mathrm{nmol} / \mathrm{min}$ per $\mathrm{mg}$ protein).

(23). Then, the automodified ADPRP was partially digested either with $\alpha$-chymotrypsin $\left(5 \mu \mathrm{g} / \mathrm{ml}\right.$ at $25^{\circ} \mathrm{C}$ for $5 \mathrm{~min}$ ) or papain-agarose $(100$ $\mu \mathrm{g} / \mathrm{ml}$ at $4^{\circ} \mathrm{C}$ for $5 \mathrm{~min}$ ). The reactions were terminated by the addition of $1 \mathrm{mM}$ PMSF or by microfiltration, respectively. The proteolytic fragments, or the intact enzyme, were immunoprecipitated with sera containing autoantibodies to ADPRP, as described above.

\section{Results and Discussion}

ADPRP consists of a single 116-kD polypeptide chain with distinct NAD-binding and DNA-binding domains (23). Even in whole cells, ADPRP is the major acceptor of the poly(ADPribosyl)ation reaction (17). Taking advantage of this characteristic, we screened human autoimmune sera for the ability to immunoprecipitate $\left[{ }^{32} \mathrm{P}\right] \mathrm{NAD}$-labeled proteins from human
CEM T lymphoblasts. Among 21 initial antinuclear antibodypositive sera that were examined by this method, one immunoprecipitated a 116-kD poly(ADP-ribosyl)ated protein (data not shown). Using this serum as a prototype, we then surveyed by immunoblotting $\sim 200$ additional specimens from patients with autoimmune diseases. A total of six sera blotted the same 116-kD band in crude HeLa cell extracts (Fig. $1 A$ ). Furthermore, each of the sera gave the same distinctive immunofluorescent pattern on HEp-2 cells, staining the nucleus diffusely, and reacting intensely with nucleoli and metaphase chromosomes (Fig. $2 \mathrm{~A}$ ). As tested by immunoblotting, purified nucleoli were also enriched in the 116-kD autoantigen (Fig. $1 B$ ). The smaller polypeptides that were immunoblotted by the antibodies in Fig. 1 were shown to be degradation fragments of the 116-kD protein, because antibodies eluted from each of the smaller bands reacted with the 116-kD band (data not shown).

To prove that the six sera specifically recognized the ADPRP protein, the enzyme was purfied 3,800-fold from calf thymus, and 1,000-fold from human thymus. During the purification steps, autoantigenic activity of ADPRP was determined by enzyme-linked immunosorbent assay (ELISA) (24). ADPRP activity and the autoantigenic activity co-eluted from both a DNA-cellulose column and a hydroxyapatite column (results not shown). As shown in Fig. 3, incubation of the purified calf thymus ADPRP with patients' IgG, coupled to protein A-Sepharose, depleted the ADPRP activity in a dosedependent manner. In control experiments, incubation of the enzyme with protein A-Sepharose beads coated with normal human serum or a control antinuclear antibody (anti-scl 70) did not alter the ADPRP activity. The purified enzyme yielded

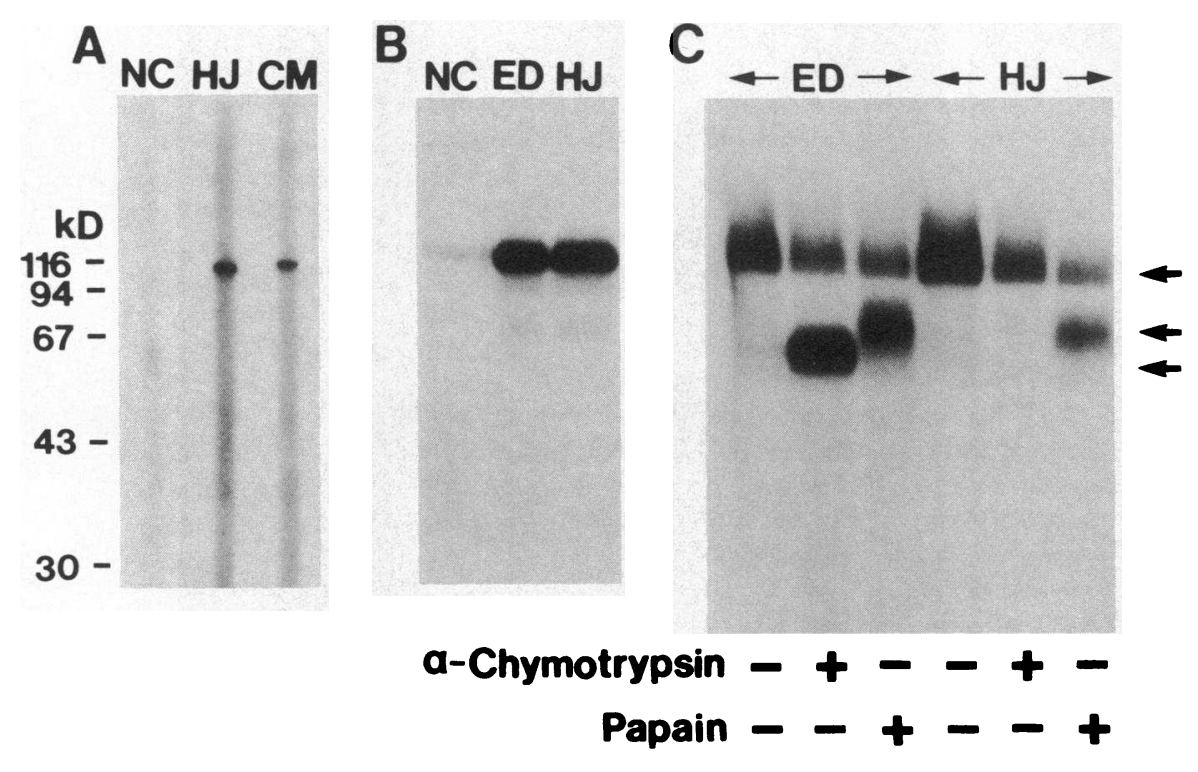

D
Figure 4. Immunoblotting and immunoprecipitation of purified ADPRP. (A) Purified ADPRP from calf thymus was fractionated by SDS- $12.5 \%$ polyacrylamide gel electrophoresis, transferred to nitrocellulose paper, and immunoblotted with a 1:100 dilution of serum from a normal control (NC), or from patients H.J. and C.M. (B) $30 \mu \mathrm{g}$ ADPRP was was autopoly(ADP-ribosyl)ated with $0.65 \mu \mathrm{M}\left[{ }^{32} \mathrm{P}\right]-$ NAD. Radiolabelled ADPRP was immunoprecipitated with IgG from a normal control (NC), or from patients E.D. and H.J., and was fractionated by SDS- $12.5 \%$ polyacrylamide gel electrophoresis and autoradiographed. $(C) 15 \mu \mathrm{g}$ ADPRP was automodified with [ $\left.{ }^{32} \mathrm{P}\right] \mathrm{NAD}$, and then was partially proteolyzed either with $\alpha$-chymotrypsin $\left(5 \mu \mathrm{g} / \mathrm{ml}\right.$ at $25^{\circ} \mathrm{C}$ for $\left.5 \mathrm{~min}\right)$ or papain-agarose $\left(100 \mu \mathrm{g} / \mathrm{ml}, 4^{\circ} \mathrm{C}, 5 \mathrm{~min}\right)$. After the termination of the reaction, the proteolytic fragments were immunoprecipitated either with the serum of patient E.D. or H.J. The arrows on the right margin of the figure show the native enzyme, the NAD-binding domain plus the automodifcation site, and the DNA-binding domain plus the automodification site, respectively, from the top. (D) The proposed components of the ADPRP polypeptide, according to Kameshita et al. (23). 
Table I. Clinical Manifestations of Patients with Anti-ADPRP Antibodies

\begin{tabular}{|c|c|c|c|c|}
\hline Patient no. & Age/sex & Presenting symptoms & Other signs and symptoms & Clinical diagnosis \\
\hline 1 & $44 / F$ & Leg paresthesias & $\begin{array}{l}\text { Parotid mass, dry eyes, } \\
\text { dry mouth } \\
\text { Elevated ESR }(44 \mathrm{~mm} / \mathrm{h})\end{array}$ & $\begin{array}{l}\text { Sjögren's syndrome } \\
\text { Sensory polyneuropathy }\end{array}$ \\
\hline 2 & $58 / \mathrm{F}$ & Myalgia with muscle weakness & $\begin{array}{l}\text { Abnormal liver function tests } \\
\text { Schirmer's test }(5 \mathrm{~mm}) \\
\text { Elevated ESR }(76 \mathrm{~mm} / \mathrm{h})\end{array}$ & $\begin{array}{l}\text { Possible Sjögren's syndrome } \\
\text { Chronic liver disease }\end{array}$ \\
\hline 3 & $62 / F$ & Myalgia + fatigue & & Sensory polyneuropathy \\
\hline 4 & $65 / M$ & Diffuse leg pain & $\begin{array}{l}\text { Elevated ESR }(48 \mathrm{~mm} / \mathrm{h}) \\
\text { Mass on chest } \mathrm{x} \text {-ray }\end{array}$ & Bronchogenic carcinoma \\
\hline
\end{tabular}

ESR, Erythrocyte sedimentation rate (Westergren method).

the same immunoblotting pattern as crude cell extracts (Fig. 4 $A)$. Similar results were obtained with the human enzyme.

Affinity chromatography was used to isolate the antiADPRP autoantibodies from the serum of one patient. Purified calf thymus ADPRP was coupled to Sepharose and incubated with patient E.D.'s serum. After extensive washing, the bound autoantibody was eluted with $0.1 \mathrm{M}$ glycine- $\mathrm{HCl}, \mathrm{pH}$ 2.5 , and neutralized. The affinity purified autoantibody gave the same immunofluorescent pattern on HEp-2 cells as whole serum (Fig. 2 B)., and also recognized the 116-kD ADPRP protein on immunoblots.

To localize the autoantigenic epitopes on ADPRP, the purified calf enzyme was automodified with $\left[{ }^{32} \mathrm{P}\right] \mathrm{NAD}$, partially proteolyzed, and then analyzed by immunoprecipitation. Previous experiments have shown that digestion of ADPRP with papain yields a 74-kD fragment that contains the NAD-binding and automodification domains (23). In contrast, digestion with $\alpha$-chymotrypsin produces a $66-\mathrm{kD}$ fragment that includes the DNA-binding and automodification domains (Fig. $4 \mathrm{D}$, reference 23). Besides reacting with the intact enzyme, two of the six sera immunoprecipitated both the 74- and $66-\mathrm{kD}$ fragments; the other four sera recognized the 74-kD fragment, but not the $66-\mathrm{kD}$ fragment (Fig. $4 \mathrm{C}$ ). These results indicate that the autoantigenic epitopes on ADPRP reside in both the DNA-binding and the NAD-binding domains. However, the failure of four sera to react with the poly(ADP-ribosyl)ated $66-\mathrm{kD}$ fragment shows that they do not contain precipitating antibodies to poly(ADP-ribose), which have been reported in lupus erythematosus (25). Consistent with this result, the sera also did not precipitate poly(ADP-ribosyl)ated histones. Nor did they contain autoantibodies against DNA, histone, n-ribonucleoprotein, Sm, SS-A(Ro), SS-B(La), Ku, or scl-70 (topoisomerase I), as measured by standard immunofluorescence, immunodiffusion, or ELISA methods $(15,26,27)$. Remarkably, each serum reacted monospecifically with ADPRP. The anti-enzyme antibodies were predominantly IgG, and contained both kappa and lambda light chains.

Clinical data on four of the patients with anti-ADPRP autoantibodies were available, and are summarized in Table I. Three patients complained of persistent neuromuscular pain, principally affecting the lower extremities, and two were considered to have a sensory polyneuropathy. One patient had classical Sjögren's syndrome. The patients with autoantibodies against ADPRP did not have any symptoms or signs of systemic lupus erythematosus, scleroderma, or rheumatoid ar- thritis. Furthermore, $>100$ sera from patients with systemic lupus erythematosus or scleroderma, that were tested by immunoblotting or ELISA, did not have anti-ADPRP antibodies. Finally, an initial survey of antinuclear antibody-positive sera from healthy blood donors failed to reveal any specimen with antibody against ADPRP.

For unknown reasons, autoantibodies against DNA-binding proteins are common in rheumatic diseases (15). Therefore, it is especially noteworthy that in the patient group reported here, the autoimmune response was directed exclusively against the ADPRP enzyme. ADPRP is the principal acceptor of poly(ADP-ribose) in cells with massive DNA strand breaks (17). Excessive activation of ADPRP in lymphocytes can impair immune responses $(13,14)$. In preliminary experiments, we have not detected any difference between the numbers of DNA breaks in the peripheral blood lymphocytes in a patient with autoantibodies against ADPRP and in normal subjects. Moreover, patients with generalized DNA repair defects have not been shown to have an increased incidence of antinuclear antibodies. However, it is still conceivable that the accumulation of DNA strand breaks in a minor population of antigen-presenting cells, whether caused by an exogenous agent or by internal metabolic changes, could lead to the modification of ADPRP. In this regard, the poly(ADP-ribose) polymer is known to be immunogenic (28), and chemically modified proteins often demonstrate increased immunogenicity. Perhaps these factors interact to promote the synthesis of autoantibodies against the ADPRP enzyme.

\section{Acknowledgments}

We thank Drs. Robert I. Fox (Research Institute of Scripps Clinic) and Marvin J. Fritzler (University of Calgary, Calgary, Alberta, Canada) for providing clinical specimens, Drs. Carlos J. Carrera and Gary H. Rhodes, and D. B. Wasson (Research Institute of Scripps Clinic) for their helpful comments and suggestions.

This research was supported in part by grants AR-25443, GM-23200, AR-32063, and RR-00833 from National Institutes of Health.

\section{References}

1. Benjamin, R. C., and D. M. Gill. 1980. Poly(ADP-ribose) synthesis in vitro programmed by damaged DNA. A comparison of DNA molecules containing different types of strand breaks. J. Biol. Chem. 255:10502-10508. 
2. Hayaishi, O., and K. Ueda. 1977. Poly(ADP-ribose) and ADPribosylation of protein. Annu. Rev. Biochem. 46:95-116.

3. Nishizuka, Y., K. Ueda, T. Honjo, and O. Hayaishi. 1968. Enzymatic adenosine diphosphate ribosylation of histone and poly adenosine diphosphate ribose synthesis in rat liver nuclei. J. Biol. Chem. 243:3765-3767.

4. Yoshihara, K., T. Hashida, H. Yoshihara, Y. Tanaka, and H. Ohgushi. 1977. Enzyme-bound early product of purified poly(ADP-ribose) polymerase. Biochem. Biophys. Res. Commun. 78:1281-1288.

5. Jump, D. B., and M. Smulson. 1980. Purification and characterization of the major nonhistone protein acceptor for poly(adenosine diphosphate ribose) in HeLa cell nuclei. Biochemistry. 19:1024-1030.

6. Berger, N. A., G. W. Shikorski, S. J. Petzold, and K. K. Kurohara. 1979. Association of poly(adenosine diphosphoribose) synthesis with DNA damage and repair in normal human lymphocytes. J. Clin. Invest. 63:1164-1171.

7. Berger, N. A. 1985. Poly(ADP-ribose) in the cellular response to DNA damage. Rad. Res. 101:4-15.

8. Creissen, D., and S. Shall. 1982. Regulation of DNA ligase activity by poly(ADP-ribose). Nature (Lond.). 296:271-272.

9. Skidmore, C. J., M. I. Davies, P. M. Goodwin, H. Halldorsson, P. J. Lewis, S. Shall, and A.-A. Zia'ee. 1979. The involvement of poly(ADP-ribose) polymerase in degradation of NAD caused by $\gamma$-radiation and N-methyl-N-nitrosourea. Eur. J. Biochem. 101:135-142.

10. Seto, S., C. J. Carrera, M. Kubota, D. B. Wasson, and D. A. Carson. 1985. Mechanism of deoxyadenosine and 2-chlorodeoxyadenosine toxicity to nondividing human lymphocytes. J. Clin. Invest. 75:377-383.

11. Yoshihara, K., A. Itaya, Y. Tanaka, Y. Ohashi, K. Ito, H. Teraoka, K. Tsukada, A. Matsukage, and T. Kamiya. 1985. Inhibition of DNA polymerase $\alpha$, DNA polymerase $\beta$, terminal deoxynucleotidyl transferase, and DNA ligase II by poly(ADP-ribosyl)ation reaction in vitro. Biochem. Biophys. Res. Commun. 128:61-67.

12. Scovassi, A. I., and R. Izzo, E. Franchi, and U. Bertazzoni. 1986. Structural analysis of poly(ADP-ribose) polymerase in higher and lower eukaryotes. Eur. J. Biochem. 159:77-84.

13. Carson, D. A., S. Seto, D. B. Wasson, and C. J. Carrera. 1986. DNA strand breaks, NAD metabolism, and programmed cell death. Exp. Cell Res. 164:273-281.

14. Carson, D. A., S. Seto, and D. B. Wasson. 1986. Lymphocyte dysfunction after DNA damage by toxic oxygen species. A model for immunodeficiency. J. Exp. Med. 163:746-751.

15. Tan, E. M. 1982. Autoantibodies to nuclear antigens (ANA): their immunobiology and medicine. Adv. Immunol. 33:167-240.
16. Hardin, J. A. 1986. The lupus autoantigens and the pathogenesis of systemic lupus erythematosus. Arthritis Rheum. 29:457-460.

17. Surowy, C. S., and N. A. Berger. 1983. Unique acceptors for poly(ADP-ribose) in resting, proliferating and DNA-damaged human lymphocytes. Biochim. Biohys. Acta. 740:8-18.

18. Francoeur, A. M., C. L. Peebles, P. T. Gompper, and E. M. Tan. 1986. Identification of $\mathrm{Ki}(\mathrm{Ku}, \mathrm{p} 70 / \mathrm{p} 80)$ autoantigens and analysis of anti-Ki autoantibody reactivity. J. Immunol. 136:1648-1653.

19. Laemmli, U. K. 1970. Cleavage of structural proteins during the assembly of the head of bacteriophage T4. Nature (Lond.). 227:680-685.

20. Celis, J. E., and A. Celis. 1985. Individual nuclei in polykaryons can control cyclin distribution and DNA synthesis. EMBO (Eur. Mol. Biol. Organ.) J. 4:1187-1192.

21. Rothblum, L. I., P. M. Mamrack, H. M. Kunkle, M. O. J. Olson, and H. Busch. 1977. Fractionation of nucleoli. Enzymatic and two-dimensional polyacrylamide gel electrophoretic analysis. Biochemistry. 16:4716-4721.

22. Carter, S. G., and N. A. Berger. 1982. Purification and characterization of human lymphoid poly(adenosine diphosphate ribose) polymerase. Biochemistry. 21:5475-5481.

23. Kameshita, I., Z. Matsuda, T. Taniguchi, and Y. Shizuta. 1984. Poly(ADP-ribose) synthetase. Separation and identification of three proteolytic fragments as the substrate-binding domain, the DNA-binding domain, and the automodification domain. J. Biol. Chem. 259:4770-4776.

24. Fong, S., T. A. Gilbertson, P. P. Chen, J. G. Karras, J. H. Vaughan, and D. A. Carson. 1986. The common occurrence of internal image type anti-idiotypic antibodies in rabbits immunized with monoclonal and polyclonal human IgM rheumatoid factors. Clin. Exp. Immunol. 64:570-580.

25. Kanai, Y., Y. Kawaminami, M. Miwa, T. Matsushima, T. Sugimura, Y. Moroi, and R. Yokohari. 1977. Naturally occurring antibodies to poly(ADP-ribose) in patients with systemic lupus erythematosus. Science (Wash. DC). 265:175-177.

26. Aarden, L. A., E. R. de Groot, and T. E. Feltkamp. 1975. Immunology of DNA. III. Crithidia luciliae, a simple substrate for the identification of anti-dsDNA with the immunofluorescence technique. Ann. NY Acad. Sci. 254:505-515.

27. Rubin, R. L., F. G. Joslin, and E. M. Tan. 1982. Specificity of anti-histone antibodies in systemic lupus erythematosus. Arthritis Rheum. 25:779-782.

28. Kanai, Y., M. Miwa, T. Matsushima, and T. Sugimura. 1974. Studies on anti-poly(adenosine diphosphate ribose) antibody. Biochem. Biophys. Res. Commun. 59:300-306. 